\title{
Syria Muslim Brotherhood After the Arab Spring
}

\author{
Rawia Altaweel \\ Chiba University, Chiba, Japan
}

\begin{abstract}
Since 2011, the Syria Muslim Brotherhood (SMB, hereafter) activism has been going through a shift at both political and military level. This paper explores various elements of this shift to explain the expansion of SMB political opportunity structure as well as the evolvement of their internal organizational structure and within the wider structure of the Syrian opposition and finally the framing approach adopted by the SMB to mobilize people and communities. The SMB's efforts to institutionalize the opposition in exile and mobilize a wider spectrum of the Syrian society including the poor and middle class have helped increase their popular bases. On the military front, SMB lack of needed experience and resources hinder their progress in the battle field. Nevertheless, SMB continued to verify its engagement strategies based on application of the opportunity and threat analysis which helped expanding its operational space as a political, military and social movement laying the ground for a presumably steady role of the SMB in the post conflict era.
\end{abstract}

Keywords: Social movement, Muslim brotherhood, Syria conflict

\section{Introduction}

This paper offers a dual dimensional analysis of Syria Muslim Brotherhood (SMB) political and militant activities and examines their evolvement strategies between 2011 and 2018.

Previous studies on SMB mainly focused on the 1970-1982 events, providing two major analysis: The first is the regime's failure to recognize the SMB's growing underground power (Rabil, 2010), and the second is the potential of unfulfilled grievances of 1982 massacre to fuel a new uprising during the Arab Spring (Lefèvre, 2013). Only few studies have examined the internal dynamics of the SMB's struggle against both the Ba'ath secular regime and the hegemony of "official Islam" (Pierret, 2009). ${ }^{1}$ Those studies, nevertheless, remain partially relative when addressing the role of SMB in the post 2011 within opposition internal dynamics and their impact on the Syria opposition composition and evolvement.

To address these questions, a review of the available publications, videos, and speeches is used to unfold the transformation in the political agenda of the SMB, especially in relation to its pre- and post- 2011 discourse in Syria. The analysis contextualizes such change of discourse within the dynamics of the recent conflict which contributed to the development of SMB's political and military strategy, including collaborations with regional and national state and non-states allies. In doing so, this paper provides insights on the factors that laid the ground for a presumably steady role of the SMB in the post conflict era.

Rawia Altaweel, Ph.D. student, Graduate School of Humanities and Study of Public Affairs, Chiba University, Chiba, Japan.

${ }^{1}$ Followed by pro-regime Sunni religious leaders who disagreed with the SMB agenda. 


\section{Conceptual Framework}

The analysis combines the opportunity structure, framing approach, and social movement theories to understand the multi-facets of SMB movement.

The key dynamic components of the political opportunity structure are the relative openness or closure of the institutionalized political system, the (in) stability of the broad set of elite alignments that typically undergird a polity, and the presence or absence of elite allies and the state's capacity and propensity for repression (McAdam, 1996). These factors once identified explain the factor behind expansion the SMB opportunity, the opportunity of other opposition groups in the same arena as well as for opponent or competitor groups after 2011.

On the one hand, the framing approach to collective action traces frames adopted by the SMB in speech or text to derive an empirical evidence of their various tactics to mobilize people and communities (Johnston, 2005). Emotional discourse combined with recreation of collective religious identity have created a wave of "perceived injustice" among younger generation who were told the stories of regime oppression of Sunni majority and subsequently generated solidarity incentives for collective action that seem to allow the expansion of SMB presence and popularity (Snow \& Benford, 1988; Goodwin, Jasper, \& Polletta, 2004; Marwell \& Oliver, 1984).

And on the other hand, SMB use of violence is seen as tactical and responding to the opportunity emerging from the need for an armed force to protect civilians from the state's violent repression and indiscriminate killings (Quintan, 2004). Social movement theory indicates that violent contention rather being an adopted way of protesting is more context related in case of lack of democracy, repressive environment, and absence of other alternatives (Della Porta, 2008; Tilly \& Tarrow, 2015). As such, Ba'ath hegemony over all political parties in Syria, including the SMB, triggered a presumably informed decision by part of Islamist supporters of violent from within the overall established non-violence movement (Khatib, 2010). Similarly, SMB military involvement in the current conflict with the caveat that during the civil war dynamics part of the militarization is merely a spell-over effect of violence fueled by international and regional interventions.

\section{Muslim Brotherhood in Syria-Historical Overview}

Having its inception in the 1942, the SMB is considered the oldest Islamic movement in post-independence Syria state. ${ }^{2}$ It started as a combination of four different charity organizations that focused mainly on education and health services in Homs, Hama, Deir ez-Zor, and Aleppo cities (Khatib, 2010, pp. 44-45), followed by founding the faculty of Islamic Jurisprudence in Damascus University in $1955 .^{3}$

The start of SMB's was among urban elite and it continued to support private property and enterprise which put it at distance from both the struggle of the rural poor and the middle class. SMB enjoyed limited political success as they had few seats in the parliament between 1946 and 1963 and was banned by Ba'ath party after seizing power in 1964.

Against the SMB leadership official position, SMB's first insurgency against Ba'ath regime in Syria was

\footnotetext{
2 Syria gained de-jure independence as a parliamentary republic on 24 October 1945, when Republic of Syria became a founding member of the United Nations, an act which legally ended the former French Mandate-although French troops did not leave the country until 17 April 1946. SMB was initially established by Moustafa Al-Sibai who studied with Hassan Al-Banna's the founder of the Muslim Brotherhood in Egypt. Despite Al Banna and Al Sibai's friendship and both movements' similar ideological foundations as Islamic political movement with social welfare agendas, each of them was established and developed in different context and faced different challenges. The Syrian MB remain independent in terms of decision making with a loosen connection to Egypt MB (Abdalla \& Algar, 1983).

${ }^{3}$ Unlike Jordan or Egypt, the faculty served as a base for more modern and progressive Islamic teachings and studies in Syria (Talhami, 2001).
} 
formed in 1976 by Marwan Hadid ${ }^{4}$ who called for "Sunni” armed struggle against the regime. His Muhammad's Battalions, that quickly renamed itself to the Fighting Vanguards (al-Talī’ah al-Muqātilah) Islamic guerilla group, attempted a 29-day revolution but failed to pose any tangible threat to the Ba'ath regime (Khatib, 2010). In retaliation, then the president Hafez Al-Assad issued decree No.49/1980 5 that punishes membership to SMB with death penalty (Abdalla \& Algar, 1983). Such attacks continued up until the infamous military operation by the government to eliminate the fighting vanguards in Hama, 1982 that caused massive civilians' causalities ${ }^{6}$. After Hama events, many of the SMB members fled the country to start a new form of political underground activism, managed from exile.

To manage the sectarian animosity resulted from 1979-1982 conflict, Assad adopted a tolerant policy to moderate Sunni Muslim groups during the 90s and 2000s. As a result, Islamic schools and charities increased, and Islamic intellectuals and businesspersons were co-opted into the parliament. Furthermore, a female-led movement, known as Al-Qubaysiyat ${ }^{7}$, has been recognized to preach Islam among upper-class Damascene women (Hinnebusch, 2013).

Although hundreds of SMB members were released from detention upon the inauguration of President Bashar Al-Assad in 2000, the SMB negotiation attempts over the return of its members in exile and lift the ban on its political activities inside the country were denied. The return of SMB members to Syria remained conditional to abandoning political activism.

Among the key documents presented and issued by SMB are: the 2001 "Project of a National Charter of Honor for Political Action in Syria” (Mashroa' Mithaq Sharaf Watany Li al-'Amal al-Siyasy fi Sūrīya) which reiterates the movement commitment to national dialogue and democratic political tools as a way for work as well as its rejection for violent actions; and the 2003 "Political Project for Future Syria" (al-Mashrū' al-Siyayi li Sūrīya al-Mustaqbal ${ }^{8}$, a detailed 127-page document that explains its vision of state formation and institutions, source of legislations, national challenges, and finally political and economic reform.

The opposition activism increased after 2000 presidential change and emenates Damascus Declaration of Democratic Change in 2005, which was signed by political opposition leaders including Islamist, Arab nationalists, Kurdish, and leftists aiming at unifying the Syrian opposition fractures. ${ }^{9}$ SMB was alienated from

\footnotetext{
${ }^{4}$ Born in 1934 in Hama for an urban merchant family, Hadid was a member of Ba'ath party and a socialist activist working for social justice until Hasan Al Banna's death in Egypt that shifted his work towards Islamic activism. In 1956, Hadid moved to Egypt to start his degree and joined Muslim Brotherhood there. He became active during his stay in Egypt and was arrested many times by the Egyptian authorities. In 1964, Hadid retuned to Syria to establish the Fighting Vanguard's. Hadid was arrested few times by the regime and died in prison in Damascus in 1976.

5 Muslim Brotherhood decree No. 49 (1980). [online] http://parliament.gov.sy/laws/Law/1980/penal_49_1980.htm [Accessed 17 Feb. 2019].

6 The massacre of Hama took place in 1982, when the Syrian Army besieged the city of Hama for a month to end the uprising of Sunni Muslim groups led by Muslim Brotherhood against the Baath government. The uprising started in 1976 and ended in 1982 with unconfirmed reports of 10-25 thousand civilians were reportedly killed (need source). Large parts of the old city of Hama were destroyed during the military operation

7 Named after its founder Munira Qubaysi, Al-Qubaysiat sisterhood (The Qubaysi women) had been established in 1970, in Syria, and supported by the Syria grand mufti Ahmad Kuftaro. The association focuses on religious Islamic teaching for women and girls.

${ }^{8}$ The full document is available only in Arabic on the official facebook page of SMB: https://bit.ly/2DKhuua, last accessed 6 April 2018.

9 Signed on 16 October 2005, Damascus Declaration for Democratic Change was a unified statement by the Syrian opposition. The initiative started as a response to popular discontent over Syria's involvement in Lebanon and its conflict with the United States over Iraq and Palestine. Signatories included historical opposition movements such as the National Democratic Rally and the Muslim Brotherhood, minority groups such as Kurdish and Assyrian parties, and prominent dissidents from the Damascus Spring movement such as Michel Kilo and Riad Seif.
} 
Damascus Declaration after joining the National Salvation Front (NSF) (Jabhat al-Khalāṣ al-Wațanīy) ${ }^{10}$ led by former vice president, Abdul Halim Khaddam, following his defection in 2006 (Carnegie Middle East Center, 2012). However, SMB has soon withdrawn due to disagreement with Khaddam on SMB's pursued negotiation with the regime for potential return into the country, efforts that were mediated through the Turkish Welfare party, an Isalmist conservative party close to the brotherhood network ${ }^{11}$, aiming at solving the long-term animosity. Ultimately, the mediation failed as the regime refused to lift the ban on the SMB.

\section{From Mediation to Regime Change: SMB Revival Post 2011}

With no political gain in sight, the internal dispute on whether to continue that way or adopt a different strategy increased. And as part of the adoption and restructuring policy, a new Controller General Mohamad Riyadh Al-Shaqfa was selected in 2010 (Lefèvre, 2013). His approach, unlike Al-Bayanouni's pacifism, was known as a "hardliner", advocating against the negotiation with the regime.

The SMB revival since 2011 was observed at various levels, including: (1) the rhetoric and discourse level, feeding into Friday demonstrations slogans and utilizing the nitrative of Hama 1982 in its mobilization campaigns; (2) revolution institutionalization, setting up forums and co-creating a consolidated body to gain international support; and (3) the military level by funding and supporting armed groups inside Syria.

\section{Revitalizing the Uprising}

Although SMB's first official statement was a year after the uprising erupted, it is believed that the SMB had discreetly encouraged its members to take part in the demonstration way before it issued an official statement towards the end of March of 2012 (Lund, 2013). "A Covenant and Pact of Syria Muslim Brotherhood" (Wathiqat 'ahd wa Mithaq) (SMB Official Website, 2012) summarizing their vision for the state in 10 points; among which are a modern civil state, a democratic republic with parliamentarian ruling system, a civil constitution, all citizens are equal despite their various ethnicities and religions, and all have a voice to elect and form the new state built on national reconciliation. The document avoids any mentioning of majority role of Muslims or the Islamic reference. Despite that this might be explained by the relatively short length of the document, the absolute absence of such wording is intriguing as it reflects a tactical maneuver to match the popular demands of the uprising.

It worth mentioning that as early as the Friday 29 April 2011, the demonstrators introduced a slogan of "no Salafi, no brotherhood, our revolution is a revolution of a human" (Lā Salafìya wa lā ikhwān, thawrat-na thawrat insān) (Ugarit News, 2011) to reject the regime claims that the revolution was merely a Muslim brotherhood revenge or another Islamist insurgency against minorities.

The SMB offered an invitation to all Syrians to start a new social contract on "that establish the ground for a citizenship relation among all Syrian society components to work together towards a modern civil state ruled by consensus and a civil constitution put together by an elected committee". Their narrative was broadening to

\footnotetext{
10 The National Salvation Front (NSF) established in Brussels in March 2006 aiming at presenting a consolidated Syrian opposition against Bashar al-Assad regime. The front is led by defector vice president Khaddam who fled the country in 2006 upon the increasing pressure of the regime after the assassination of Lebanese prime minister Rafic Hariri and Syria's withdrawal from Lebanon in 2005. During that time, NSF was Syria's largest opposition party in exile.

11 The Welfare Party in Turkey is an Islamic party established in 1983 and was banned in 1998 by the Constitutional Court due to violation of separation of state and religion as mandated by the constitution. The incumbent president, Recep Tayyip Erdoğan, was a former member of the party. After being banned from politics for a period, he left this Islamist group and founded the Justice and Development Party (AKP). Abdullah Gül, the former President of Turkey, was the deputy leader of the Welfare Party until its dissolution.
} 
accommodate all ethnicities and sects in a democratic state (Dawla Dimoqratyia tadhum Kul Fi'at al-Sha'ib al-Suri); that is more focus on internal Syrian issues and less emphasize on regional issues, such as the Palestinian issue for example.

\section{Institutionalization of the Revolution}

SMB has played an important role in organizing Syria's pollical opposition and forming its first political umbrella body: Syrian National Council (SNC) in August 2011 (Hassan, 2013). Since its formation, the SNC contained a large Islamic component composed of the SMB and another Islamic bloc of 74 members of former SMB members as businessmen affiliates to SMB. Initially, SMB membership formed only 8 out of the 42 founding members in the SNC general secretariat and 20 in the SNC general assembly ${ }^{12}$-less than 10 per cent of the total 310 seats $^{13}$. By 2012, the SMB said to occupy at least a quarter of the SNC 310 seats (Carnegie Middle East Center, 2013a).

Despite moderate official representation, the SMB had a profound influence on the decision-making process as it managed the SNC offices for military affairs and humanitarian aid. It had key persons in executive and general board as well as affiliates-independent or members of other parties.

To mitigate the criticism for SMB's power, SMB resorted to vote for leaders with secular profiles and supported credible intellectuals and left-wing personas, like Burhan Galioun ${ }^{14}$, Abdelbaset Sida ${ }^{15}$, and George Sabra $^{16}$ to lead the SNC (Lund, 2013). On the other hand, the increasing international pressure for inclusive representation in the Syria opposition has led to the establishment of the National Coalition of Syrian Revolutionary and Opposition Forces (al-'itilaf al-Watany li qua al-Thawra wa al-Mo'aradha)-hereafter referred to as the Syrian Coalition, and received recognition by over 100 states including gulf countries, the Arab League, main EU countries as well as the United States of America (Carnegie Middle East Center, 2013b).

\section{Political Upgrade to Connect With Community}

In January 2014, the SMB, together with the attendance of some Christian, Alawites, and Kurdish politicians, launched a new political party: The Justice and Constitution National Party (al-Hizb Al-Wataniy lil 'adala wa al-Dustour- WAED). Although presented as an independent national party with moderate Islamic vision, WAED's party first leader, Mohammad Hikmet Waleed, was an SMB member and has become the SMB's Controller General since $2014^{17}$.

\footnotetext{
12 Interview with Tarif al-Sayed Issa an SMB member and a SNC member in Lund (2013).

13 The membership of the SNC was later increased to 400 members.

14 Born in 1945 in Homs, Burhan Ghalioun is a Syrian thinker, a director of the Centre d'Etudes sur l'Orient Contemporain (Ceoc) in Paris, and a professor of political sociology at the Université de Paris III (Sorbonne Nouvelle). Ghalioun was named the first chairman of the SNC in August 2011. Main criticisms against him were his closeness to SMB and reluctance to support armed opposition action. He resigned in May 2012.

15 Born in 1956 in Amuda-Al Hassaka governorate, Abdelbaset Sida is a Kurdish-Syrian academic and politician. Sida has a Ph.D. in Philosophy from Damascus University and he has lived in Sweden since 1994. He is the former President of the Syrian National Council (SNC), succeeding Burhan Ghalioun in June 2012 (AlJazeera, 2012).

16 George Sabra, born in 1947 to a Christian family in Qatana city of rural Damascus governorate, graduated with a geography degree and worked as a school teacher. He has been politically active as a leftist, pro-Arab, secular opposition since 70s when he joined the Syrian Communist Party (Political Bureau) and was later elected to its Central Committee in 1985. Sabra was a co-founder of the Damascus Declaration opposition coalition in 2005, and in the same year, the Syrian Communist Party (Political Bureau) changed its name to the Syrian Democratic People's Party (Carnegie, n.a).

17 Waleed is the first CG from Lattakia- a coastal region in Syria, and where the president family is originally from. Lattakia is considered a Regime's strong hold, with majority alawites. Previous leaders of SMB were all from Homs, Hama, and Aleppo, cities of traditionally known with considerable popular base for Sunni and SMB activism.
} 
More importantly is SMB reconsideration of the role of youth and women since the hegemony of 70-80 years old men in senior leadership and decision-making positions posed as a serious challenge in attracting younger fellowship in both political and militant levels (Lefèvre, 2015). Despite the SMB publicity on women engagement remains very modest, SMB founded the Syria Muslim Sisters (al-'akhawat al-muslimat) group in 2013 that took the lead in establishing NGOs and charities to provide relief aid to Syria refugees in Turkey. The sisters reportedly have a strong role at the youth committees and their membership ration reached 10 per cent (SASA Post, 2015). A female member attributed women's low representation to the prevailing security situation. Interestingly, women are occupying more executive positions in charities responsible of implementation of activities that invests a considerable share of SMB financial resources (Lefèvre, 2013). However, SMB women's participation is still smaller in both quantity and quality and with no direct engagement in political action.

\section{SMB Military Involvement}

SMB's non-violence and peaceful approach in 2011 has quickly changed as a contextual necessity imposed by the increasing oppression of the state and the conductive environment of resources availability and international support for the free Syrian Army (al-Jaysh as-Sūrī al-Hurr, FSA hereafter) on 29 July 2011 (Landis, 2011).

For the primary reason of defending the civilians, SMB announced the establishment of the Shields of the Revolution Council (Hayat Duru al-Thawra, Shields hereafter) ${ }^{18}$ saying that

recently and in order to unify brigades and battalions that have moderate thinking, which is the faith of SMB as well, we called them for a meeting in Istanbul and the result was the establishment of the Shields which is an independent committee of an Islamic ideology similar to ours, however this is not an official arm wing to the SMB [...] We all know that militants on the ground are so disparate for support and will affiliate with anyone who provide fund and arms. (Okaz, 2013a)

The Shields shared with SMB are not only a common ideology and moderate Islamic thinking, but also its visual identity with a peace pigeon instead of Quran, in the middle top of two crossed swords, referring to the peaceful demonstrations (see Figure 1). ${ }^{19}$

\footnotetext{
${ }^{18}$ Revolutionary Shield Committees established in September 2012 and officially launched in Istanbul in December 2012 in a ceremony attended by the leader of SMB and the Free Syrian Army. The main mission is said to be the protection the peaceful popular movement against the violent attacks by the regime (The Revolution Shields, 2012)

19 The official twitter account of the Shields: https://twitter.com/revoshields?lang=en.
} 


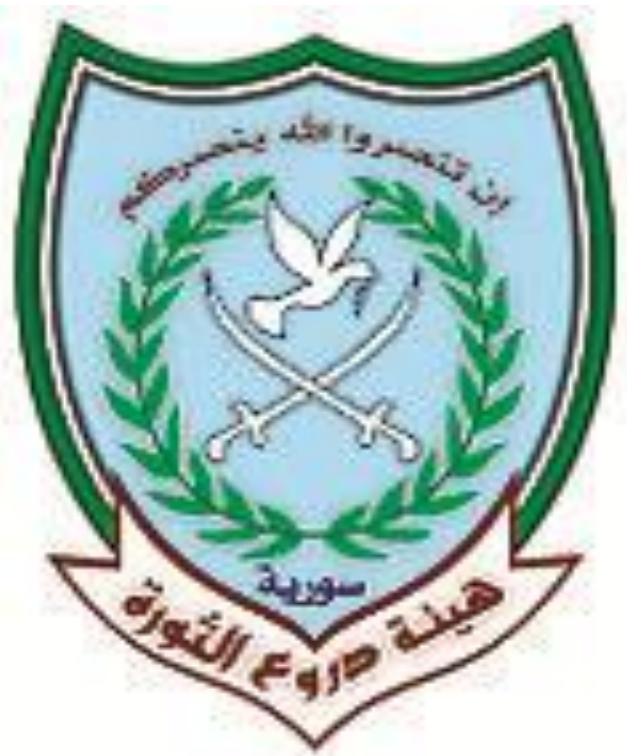

(a) The revolutionary shields emblem.

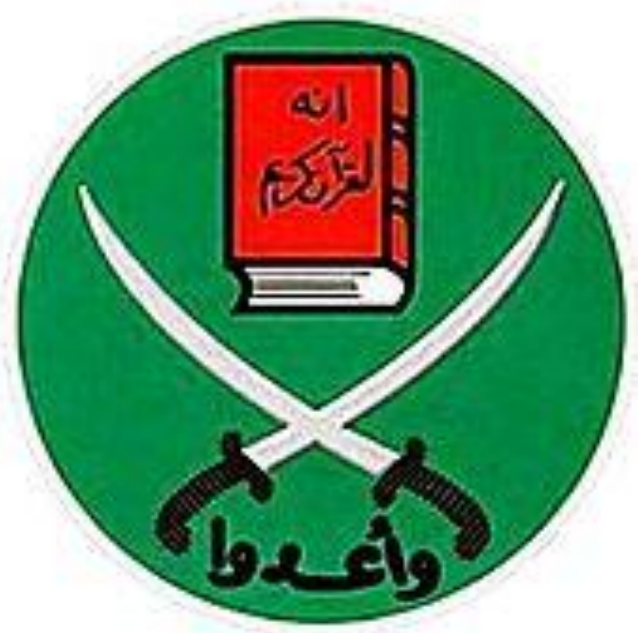

(b) The Syria muslim brotherhood emblem.

Figure 1. The emblem of Syrian Muslim brotherhood versus the emblem of the Shields of Revolution Council.

Moustafa Al-Sheikh, founder and head of the Free Syrian Army's Higher Military Council in 2012, opposed the SMB operation modality doubting their commitment towards a civil state as they "supported and funded the civilian protection units [in a reference to the revolutionary shields]" instead of supporting FSA. He considered "such activity from SMB side (...) a partition factor hinders the consolidation of the armed forces of Syrian opposition" (Okaz, 2013b). SMB's support for Islamic groups over FSA has been considered to weaken the structure of a unified opposition army and reflect negatively on the secular nature of the Syrian uprising, leading to the rise of Jihadist (NewSyrian.net, 2017).

Although SMB distincts itself from the Salafist radical groups and denounces terrorism, emphasizing Jihad as a forced self-defense mechanism, armed forces have become gradually more politicized due to regional interference leading Failaq al-Sham to detach from SMB to pursue Saudi Arabia financial support (Lefèvre \& El Yassir, 2014) as the latter has listed MB on a sanction list and issued legislation against individuals affiliated 
with it, punishing them with up to 20 years in prison (BBC, 2014).

What special about the SMB military involvement, although small in scale in comparison with other major fronts and alliances, is first, the tactical and strategic positioning both in the battlefields and amid various fractions of armed militias; and second, the collective grievance narrative that connect current battels to the history of Syria and more particularly the particularly the Islamic insurgency against Ba'ath regime.

An example of possible dual role of SMB is Tarif Al-Sayyed Issa who is an SMB member and a field commander of SMB affiliated Failaq Al-Sham, reflecting the inter-twined relation between SMB and Islamic militias. Issa, originally from Idlib governorate, has been previously a member of the SNC and joined armed activities upon the mobilization for the retake of Idleb from the government control (Lund, 2015). Such a dual experience of SMB fighters who were originally more politically active and now been given the chance to fight against the regime within the armed opposition groups has also contributed to them playing an instrumental role in mediating and brokering negotiations amongst other opposition groups. For instance, Failaq Al-Sham was able to play an instrumental role in mediating the recent dispute and ceasefire in Idlib, February 2018, between Hayat Tahrir Al-Sham (Hay'at Taḥīir al-Shām) ${ }^{20}$ - HTS and Syria Liberation Front (SLF) (Enab Baladi, 2018).

In August 2016, Jaish Al Fatah ${ }^{21}$ (including Failaq Al Sham ${ }^{22}$ ) carried out a major military offense to retake the military college in Aleppo, the operation was named after Ibrahim Al Yousuf, a Fighting Vanguards' member who took part in similar attack in 1980s that executed tens of mostly Alwites military cadets as a retaliation against Ba' ath regime (Halab Today TV, 2016). ${ }^{23}$ Worth mentioning that SMB has disclaimed responsibility for the attack on the artillery college in the 80s and clarified that Ibrahim Al Yousef was not an SMB member. However, the situation was different in 2016 as SMB announced its on-ground-support for militant activities against the regime, in this case supporting with ground fight to break the government militant forces encirclement of east Aleppo in October $2016^{24}$. The SMB had quickly issued a statement celebrating the achievement and calling for

this victory to be invested at political and civil levels, to ensure the military political complementarities as well as at civil level to manage the liberated territories to serve the revolution hosting community. We also plea to the international community and our Arabs and Muslim brothers to support for humanitarian and relief efforts in Aleppo and finally work

\footnotetext{
${ }^{20}$ Hay'at Tahrir al-Sham (Levant Liberation Committee, abbreviated as HTS) is an active Salafist jihadist militant group formed in January 2017 as a merger between Jabhat Fateh al-Sham (formerly al-Nusra Front), the Ansar al-Din Front, Jaysh al-Sunna, Liwa al-Haqq, and the Nour al-Din al-Zenki Movement. After the announcement, additional groups and individuals joined reaching more than 31,000 fighters. HTS has been accused of working as al-Qaeda's Syrian branch as many of the group senior figures held similarly extreme views. HTS has officially denied being part of al-Qaeda, however, many groups and individuals defected from Ahrar al-Sham, representing their more conservative and Salafist elements and joined HTS. Recently, Ansar al-Din Front and Nour al-Din al-Zenki Movement split off from Tahrir al-Sham claiming that Tahrir al-Sham shares al-Nusra Front's goal of turning Syria into an Islamic emirate run by al-Qaeda.

${ }^{21}$ Jaish al-Fateh, literally translated as the Army of Conquest, was formed in 2015 as an alliance of Islamic militias active in Idleb governorate bordering Turkey and some areas of Lattakia and Hama governorates. The alliance is supported by Qatar, Saudi Arabia and Turkey and presents their common interest in Syria (Sengupta, 2015).

${ }^{22}$ Failaq al-Saham, literally translated as Levant Legion, is an alliance formed of 19 smaller fractions in 2014 most of them were previously part of the revolutionary shields affiliated with SMB (Syria 360,2014). In 2015, Failaq al-Sham joined Jaish al-Fateh in new alliance.

23 The extreme right-wing Sunni did not consider Alawites as Muslim, the Syrian Muslim brotherhood insisted to have it stated in the Syrian constitution that the religion of the president of the Syrian state should be Muslim. In that sense some of them considered the country is ruled by non-Muslim as a reason for Jihad.

${ }^{24}$ The battle for Aleppo continued for four years 2012-2016 where the city was divided into government held west Aleppo and opposition controlled east Aleppo. The major challenge for both sides was supplies routes to both sides. The city finally fell into the regime control in December 2016 after consecutive military offences by the government army supported by Russia air forces (Mroue, 2016).
} 
together to save the unity of Syria land and people. ${ }^{25}$

\section{Conclusion}

The Syrian uprising and following armed conflict provided an opportunity to the SMB to transform, restructure and re-shape as the Syrian political scene evolves. The SMB appeared to go through a shift from being an isolated party in exile to one that has front seat at various forms; be that through the revolutionary interim government and negotiation table, fighting militias on the ground, or political representation at the community level.

SMB's narrative that combine its religious identity represented with Hama grievances and national inclusion of various sectarian and ethnic groups as well as the SMB internal and external transformation of leadership and establishment of affiliated party or charities has helped expanding their popular base and proved their ability to undertake a process of learning and accommodating of fluid dynamics, which has often reflected on the SMB political discourse. It also managed, despite general disagreement and mistrust, to be acknowledged by other opposition political forces.

While SMB's efforts to institutionalize the opposition in exile and mobilize a wider spectrum of the Syrian society including the poor and middle class (were significant), lack of experience and modesty of resources put its militant involvement in critical situation. SMB has adopted certain tactics of engagement based on the evolving context which made the application of the opportunity and threat analysis by SMB expanding from politics to military and civil engagement and (subsequently) providing the movement with a bigger operational space. As such, SMB has certainly the will and the needed community-base to be part of Syria state's new administration, however, the size and volume of that part is yet to be determined.

\section{References}

Abdalla, F. U., \& Algar, H. (1983). The Islamic struggle in Syria. Berkeley: Mizan Press.

Alhayat Newspaper. (2001). In "The Project of a National Charter of Honor for Political Action in Syria”, Syria Brotherhood are committed to national dialogue, democracy and refusing violence. Retrieved Mar. 12, 2019, from http://www.alhayat.com/article/1089428

AlJazeera. (2012). Profile: Syria's Abdulbaset Sieda. Retrieved Feb. 17, 2019, from https://www.aljazeera.com/news/middleeast/2012/06/2012610104023429809.html

AlWasel, Z. (2013). Explained his relations to brotherhood. Burhan Ghalioun: America seized its support to the revolution and the regime planted persons in the national Council. Retrieved Feb. 17, 2019, from https://www.zamanalwsl.net/news/article/35222

Baczko, A., Dorronsoro, G., \& Quesnay, A. (2018). Civil war in Syria: Mobilization and competing social orders. Cambridge: Cambridge University Press.

British Broadcasting Corporation (BBC). (2012). Syrian National Council head Burhan Ghalioun “to resign”. Retrieved Feb. 17, 2019, from https://www.bbc.co.uk/news/world-middle-east-18106592

BBC. (2014). Saudi Arabia declares Muslim Brotherhood “terrorist group". Retrieved Feb. 17, 2019, from https://www.bbc.co.uk/news/world-middle-east-26487092

Carnegie Middle East Center. (2012). Syria in crisis: The Damascus Declaration. Retrieved Feb. 17, 2019, from https://carnegie-mec.org/diwan/48514?lang=en

Carnegie Middle East Center. (2013a). The Syrian National Council. Retrieved Feb. 17, 2019, from http://carnegie-mec.org/diwan/48334?lang=en

${ }^{25}$ Full text of the statement in available on Asharq Alarabi Center for Strategic and Civilization Studies, London, published on 8 August 2016, https://bit.ly/2SGw00j, last accessed on 18 February 2019. 
Carnegie Middle East Center. (2013b). National coalition for Syrian Revolution and opposition forces. Retrieved Feb. 17, 2019, from https://carnegie-mec.org/syriaincrisis/?fa=50819

Carnegie Middle East Center. (n.a). George Sabra. Retrieved Feb. 17, 2019, from https://carnegie-mec.org/syriaincrisis/?fa $=48732$

Della Porta, D. (2008). Research on social movements and political violence. Qualitative Sociology, 31(3), 221-230.

Ehteshami, A., Hinnebusch, R., Huuhtanen, H., Raunio, P., Warnaar, M., \& Zintl. T. (2013). Authoritarian resilience and international linkages in Iran and Syria. In S. Heydemann and R. Leenders (Eds.), Authoritarianisms: Governance, contestation, and regime resilience in Syria and Iran (pp. 222-242). California: Stanford University Press.

Enab Baladi. (2018). “Al-Sham Abraigade” stands neutral in "Aleppo Fight”. Retrieved Feb. 17, 2019, from https://www.enabbaladi.net/archives/209719

Goodwin, J., Jasper, J. M., \& Polletta, F. (2004). Emotional dimensions of social movements. In D. A. Snow, S. A. Soule, and H. Kriesi (Eds.), The Blackwell companion to social movements (pp. 413-432). Maiden, MA: Blackwell. Goodwin

Halab Today TV. (2016). Yasser Abdel-Rahim, the chief of Aleppo operation room: Ibrahim al-Youself Invasion Battle. Retrieved Feb. 17, 2019, from https://www.youtube.com/watch?v=-SIhsBljjsA

Hassan, H. (2013). How the Muslim Brotherhood Hijacked Syria's Revolution. Foreign Policy. Retrieved Feb. 17, 2019, from https://foreignpolicy.com/2013/03/13/how-the-muslim-brotherhood-hijacked-syrias-revolution/

Hinnebusch, R. (2004). Syria: Revolution from above. London and New York: Routledge.

Hinnebusch, R. (2012). Syria: From “authoritarian upgrading” to revolution? International Affairs, 88(1), 95-113.

Hinnebusch, R. (2013). Syria. In Lust, E. (Ed.), The Middle East (14th ed., pp. 790-792). Washington DC: CQ: Press.

Jazmati, H. (2018). Mulhem al-Dorbui: Biography of a reformer from Muslim Brotherhood. Retrieved Feb. 17, 2019, from https://bit.ly/2MLfdD7

Johnston, H. (2005). Comparative frame analysis. In Johnston, H., and Noakes, J. A. (Eds.), Frames of protest: Social movements and the framing perspective (pp. 237-260). Lanham, Maryland: Rowman \& Littlefield Publishers.

Khatib, L. (2010). Islamic and Islamist Revivalism in Syria: The rise and fall of secularism in Ba'thist Syria (Doctoral dissertation, McGill University Library, Quebec).

Landis, J. (2011). Free Syrian Army founded by seven officers to fight the Syrian Army. Syria Comment. Retrieved Feb. 17, 2019, from https://www.joshualandis.com/blog/free-syrian-army-established-to-fight-the-syrian-army/

Lefèvre, R. (2013). The Muslim Brotherhood prepares for a comeback in Syria. Washington D.C: Carnegie Endowment for International Peace.

Lefèvre, R. (2015). The Syrian Brotherhood's Islamic state challenge. Washington D.C: Carnegie Endowment for International Peace.

Lefèvre, R., \& El Yassir, A. (2014). The Sham Legion: Syria's Moderate Islamists. Washington D.C: Carnegie Middle East Center.

Lund, A. (2013). Struggling to adapt: The Muslim Brotherhood in a New Syria. Washington D.C: Carnegie Endowment for International Peace.

Lund, A. (2015). Going home: An interview with Tarif al-Sayyed Issa. Retrieved Feb. 17, 2019, from http://carnegie-mec.org/diwan/61724

Marwell, G., \& Oliver, P. (1984). Collective action theory and social movements research. Research in Social Movements, Conflict and Change, 7(27), 1988.

McAdam, D. (1996). Conceptual origins, current problems, future directions. In D. McAdam, J. D. McCarthy, M. N. Zald, and N. Z. Mayer (Eds.), Comparative perspectives on social movements: Political opportunities, mobilizing structures, and cultural framings (pp. 23-40). Cambridge: Cambridge University Press.

Mroue, B. (2016). Syria rebels try to break government siege in Aleppo. Retrieved Feb. 17, 2019, from https://www.usatoday.com/story/news/world/2016/08/06/syria-rebels-try-break-government-seige-aleppo/88336208/

National Coalition Council-Revolution and Opposition Forces. (n.a). Syrian local councils. Retrieved Feb. 17, 2019, from http://en.etilaf.org/coalition-components/syrian-local-councils.html

Newsyrian.net. (2017), Muslim Brotherhood rule in making the revolution fails, by Al-Hamadi, M a previous speaks person on the Hama Local Coordination Committees and the Military Council, currently based in Gaziantep, Turkey. Retrieved Apr. 9 2018, from, https://bit.ly/2siREGi

Newsyrian.net. (n.a). Mulhem al-Dorubi in a tough discussion about Muslims Brotherhood in Syria. Retrieved Feb. 17, 2019, from https://bit.ly/2DO8Ooe 
Nohlen, D., Grotz, F., \& Hartmann, C. (2001). Elections in Asia and the Pacific: A data handbook (Vol. I: Middle East, Central Asia, and South Asia). Oxford: Oxford Scholarship Online.

Okaz. (2013a). Exposing Iran 10 times failure, the Controller General of SMB: Hesitation of the West accelerate "extremism" and Syria will not be an Iraq or a platform for revenge. Retrieved Feb. 17, 2019, from https://www.okaz.com.sa/article/535393/_

Okaz. (2013b). Confirming a foreign party in Al-Asaad's assassination attempt...the spokesperson for SFA: We refuse foreign hegemony... and the liberation of Damascus Airport is soon. Retrieved Feb. 17, 2019, from https://bit.ly/2GMYZJK_

Pierret, T. (2009). Sunni clergy politics in the cities of Ba'thi Syria. In F. H. Lawson (Ed.), Demystifying Syria. London: Saqi Books.

Pinto, H., \& Gabriel, P. (2017). The Shattered Nation: The sectarianization of the Syrian conflict. In N. Hashemi and D. Postel (Eds.), Sectarianization: Mapping the new politics of the Middle East (pp. 123-142). Oxford: Oxford University Press.

Quintan. W. (2004). Introduction. In W. Quintan (Ed.), Islamic activism: A social movement theory approach (p. 21). Bloomington and Indianapolis: Indiana University Press.

Rabil, R. G. (2010). The Syrian Muslim Brotherhood. In B. Rubin (Ed.), The Muslim Brotherhood: The organization and policies of a global Islamist movement (pp. 73-88). New York: Palgrave Macmillan.

SASA Post. (2015). How does Muslim Brotherhood Manages its Basis inside Syria? Retrieved Feb. 17, 2019, from https://www.sasapost.com/how-the-muslim-brotherhood-in-syria-manages-the-rules-of-the-organization-now/

Snow, D. A., \& Benford, R. D. (1988). Ideology, frame resonance, and participant mobilization. International Social Movement Research, 1(1), 197-217.

Syria 360-Internationalist News Agency. (2014). Ninteen Syrian Opposition Groups Unite under “Al-Sham Legion”. Retrieved Feb. $17, \quad 2019, \quad$ from https://syria360.wordpress.com/2014/03/11/nineteen-syrian-opposition-groups-unite-under-al-sham-legion/

Syria Muslim Brotherhood (SMB) Official Page. (2012). A covenant and a pact from Syria Muslim Brotherhood. Retrieved March 12, 2019, from https://bit.ly/2QkOVMh

Syrian Human Rights Committee. (2003). The massacre of the Military Artillery School at Aleppo-Special Report. Retrieved Feb. 17, 2019, from http://www.shrc.org/en/?p=19785

Syrian National Council. (n.a.). Syrian Nation Council Mission \& Program. Retrieved Feb. 17, 2019, from http://www.syriancouncil.org/en/structure/executive-commitee.html

Talhami, G. (2001). Syria: Islam, Arab Nationalism and the Military. Middle East Policy, 8(4), 110-127.

The Guardian. (2011). Syria: 5,000 dead in violence, says UN human rights chief. Retrieved February 2, 2019, from https://bit.ly/2SV1Eqe

The Revolution Shields. (2012). A statement on launching the Military Department of the Syrian Revolution Shields. Retrieved February 2, 2019, from https://www.youtube.com/watch?v=ecldcfDTPOE

Tilly, C., \& Tarrow, S. (2015). Contentious politics. New York: Oxford University Press.

Ugarit News. (2011). Video on Homs, Talkalakh city demonstrations posted on 30 April 2011. Retrieved March 12, 2019, from https://www.youtube.com/watch?v=WbaimhRMPZY

Van Dam, N. (2011). The struggle for power in Syria: politics and society under Asad and the Ba'th Party. London and New York: IB Tauris. 